\title{
Mucin Degradation in Human Colon Ecosystems
}

\author{
EVIDENCE FOR THE EXISTENCE AND ROLE OF BACTERIAL \\ SUBPOPULATIONS PRODUCING
}

GLYCOSIDASES AS EXTRACELLULAR ENZYMES

\author{
LANSING C. Hoskins and ERwin T. Boulding, Division of Gastroenterology, \\ Veterans Administration Medical Center and the Department of Medicine, \\ Case Western Reserve University School of Medicine, Cleveland, Ohio 44106
}

A B S T RACT Recent work indicates that subpopulations of human fecal bacteria, averaging $\sim 1 \%$ of the total viable fecal flora, degrade the oligosaccharide side chains of hog gastric mucin, which structurally resembles human epithelial mucins. Here we report studies to determine whether degradation of mucin oligosaccharides is related to glycosidase production by bacteria growing in anaerobic fecal cultures. Triplicate cultures containing hog gastric mucin were inoculated with serially diluted feces from each of seven healthy subjects. When the stationary growth phase was attained, mucin oligosaccharide degradation and both cell-bound and extracellular activities of four glycosidases were measured in each culture. Cell-bound $\beta$ D-galactosidase, $\beta-N$-acetylglucosaminidase, and sialidase were present in bacteria growing at all levels of fecal inocula, including $10^{-11} \mathrm{~g}$. In contrast, extracellular activities were present in every culture inoculated with $10^{-4}-10^{-7} \mathrm{~g}$ feces, but were diminished or absent in cultures inoculated with $10^{-8}-10^{-11} \mathrm{~g}$ feces. Bacterial autolysis was an unlikely cause of extracellular glycosidase activity, since $p$-nitrophenyl- $\alpha$-Lfucosidase remained cell bound in cultures at every level of fecal inoculum. Degradation of mucin oligosaccharides was associated with extracellular, but not with cell-bound $\beta$-D-galactosidase, $\beta$ - $N$-acetylglucosaminidase, and sialidase. Among the seven subjects, the estimated most probable numbers (MPN) of fecal bacteria producing extracellular $\beta$-D-galactosidase, $\beta$ $N$-acetylglucosaminidase, and sialidase ranged from $10^{6}-10^{10} / \mathrm{g}$ dry fecal wt, were comparable to the MPN of mucin-degrading bacteria, and were significantly smaller than the MPN of total fecal bacteria.

Received for publication 30 June 1980 and in revised form 19 September 1980.
We interpret these findings as evidence for the existence of bacterial subpopulations in the normal fecal flora that produce extracellular glycosidases, and that these subpopulations have a major role in degrading the complex oligosaccharides of mucin in the gut lumen.

\section{INTRODUCTION}

Among the potentially important catabolic activities of the enteric microflora is the degradation of structural macromolecules such as mucus glycoproteins and cell membrane glycolipids. Enteric bacteria degrade both the carbohydrate and the protein moieties of mucin glycoproteins, the former extensively (1-3). This requires that bacteria produce glycosidases with the appropriate specificities for each of the glycoside linkages within the oligosaccharide side chains, as well as proteases that act on the polypeptide core. Although a variety of enteric bacteria produce glycosidases active against synthetic substrates in pure culture (4), and such activities have been measured in cecal contents (5), feces (6), and anaerobic fecal cultures (2), little is known about the fecal population densities of glycosidase-producing bacteria that degrade mucin oligosaccharides.

To define better the bacterial populations involved in gut mucin degradation, we have studied degradation of hog gastric mucin (HGM) ${ }^{1}$ in liquid anaerobic fecal cultures. The oligosaccharide side chains of HGM (Fig. 1) resemble those of human ovarian cyst and gastric mucins (8) in being branched structures consisting principally of beta-linked D-galactose and $\mathrm{N}$-acetyl-

\footnotetext{
${ }^{1}$ Abbreviations used in this paper: $\mathrm{CV}$, coefficient of varia-
} tion; HGM, hog gastric mucin; MPN, most probable number. 


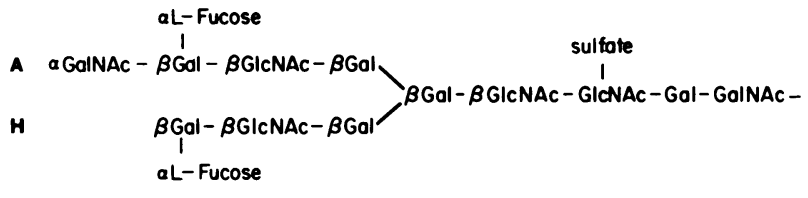

FIGURE 1 Structure proposed by Slomiany and Meyer (7) for the oligosaccharide side chain of a sulfated glycoprotein from hog gastric mucosa showing blood group $\mathrm{A}$ and $\mathrm{H}$ antigen chains. Abbreviations: Gal, D-galactose; GalNAc, $N$-acetylgalactosamine (2-deoxy-2-acetamido-D-galactose); GlcNAc, $N$ acetylglucosamine (2-deoxy-2-acetamido-D-glucose).

glucosamine residues, with alpha-linked glycosides at the nonreducing end that confer blood group $\mathrm{A}, \mathrm{B}, \mathrm{H}$, and Lewis activity (man), and $\mathrm{A}$ and $\mathrm{H}$ activity (hog). Degradation of the side chain shown in Fig. 1 would require a minimum of five exoglycosidases: an A-degrading $\alpha$ - $N$-acetylgalactosaminidase, an $\mathrm{H}$-degrading $\alpha$-Lfucosidase, $\beta$-D-galactosidases and $\beta$-N-acetylglucosaminidases with appropriate linkage specificities acting sequentially along the chain, and an $\alpha-N$-acetylgalactosaminidase cleaving the linkage of the first saccharide with either serine or threonine. We have recently found that mucin degradation in 11 healthy subjects was associated with bacterial subpopulation(s) constituting $\sim 1 \%$ of the total fecal flora and numbering $10^{8}-10^{9}$ organisms/g fecal dry wt in most subjects. (9). ${ }^{2}$ We have previously shown $(10,11)$ that the glycosidases required for cleavage of the alpha-linked terminal $\mathrm{ABH}$-determinant glycosides were produced by bacterial subpopulations with fecal population densities averaging $\sim 10^{7}-10^{8} / \mathrm{g}$ fecal wet wt. In this paper we report studies investigating the relationship between mucin degradation and bacterial production of $\beta$-D-galactosidase, $\beta$ - $N$-acetylglucosaminidase, and sialidase in replicate anaerobic cultures inoculated from serially diluted feces. Sialidase was studied because sialic acid is present in intestinal goblet cell mucins $(12,13)$. The results suggest that degradation of mucin oligosaccharides is associated with subpopulations of enteric bacteria that produce these glycosidases as extracellular enzymes.

\section{METHODS}

Materials. Stool samples were obtained from seven healthy subjects who had not received antibiotics for at least 6 mo. Their mean age was $49 \mathrm{yr}$ (range $32-57 \mathrm{yr}$ ). Two were females, and all were secretors of their blood group antigen. Samples were inoculated within $1 \mathrm{~h}$ of defecation in six subjects. The mean $\pm S D$ dry fecal weight from the seven subjects was $27.0 \pm 4.7 \%$ of wet weight.

Anaerobic culture medium, described elsewhere, ${ }^{2}$ was a semidefined medium containing acid-hydrolyzed casein, minerals, vitamins, purine bases, uracil, and $1 \mathrm{mg} / \mathrm{ml} \mathrm{D}$-glucose. Growth was limited by monosaccharide concentration.

${ }^{2}$ Miller, R. A., and L. C. Hoskins. To be published.
Commercial HGM (Lot 6901, ICN Pharmaceuticals, Inc., Life Science Group, Cleveland, Ohio), purified by twice precipitating it from $60 \%$ ethanol followed by dialysis and lyophilization, was dissolved in the medium at a final concentration of $2 \mathrm{mg} / \mathrm{ml}$ dry wt. Sterile vitamin $K_{1}$ and hemin solutions (14) were added to the autoclaved medium at final concentrations of 0.5 and $5 \mu \mathrm{g} / \mathrm{ml}$, respectively.

Serum $\alpha_{1}$-acid glycoprotein was a gift from the National American Red Cross Blood Products Laboratory, Washington, D. C. Asialo- $\alpha_{1}$-acid glycoprotein was prepared by incubating $\alpha_{1}$-acid glycoprotein with Clostridium perfringens neuraminidase (type VIII, Sigma Chemical Co., St. Louis, Mo.) until $96 \%$ of the acid-hydrolyzable sialic acid had been released. The product was heated $10 \mathrm{~min}$ at $100^{\circ} \mathrm{C}$, then dialyzed extensively against distilled water and lyophilized. Asialo-agalacto- $\alpha_{1}$-acid glycoprotein was prepared by incubating asialo$\alpha_{1}$-acid glycoprotein with Jack Bean $\beta$-galactosidase (grade VII, Sigma Chemical Co.) until $72 \%$ of the theoretical galactose content of asialo- $\alpha_{1}$-acid glycoprotein had been released. The mixture was heated $10 \mathrm{~min}$ at $100^{\circ} \mathrm{C}$, dialyzed against distilled water, and lyophilized.

$p$-Nitrophenyl glycopyranoside substrates were obtained from Sigma Chemical Co. All other chemicals were reagent grade.

Anaerobic techniques. Medium preparation, storage, inoculation, and incubation were performed in an atmosphere of $\begin{array}{llll}95 \% & \mathrm{~N}_{2}-5 \% & \mathrm{CO}_{2} & \text { that had been passed over copper at }\end{array}$ $450^{\circ} \mathrm{C}$ to remove traces of oxygen $(10,14)$.

Inoculation, incubation, and harvest of cultures. A weighed aliquot of fresh feces was dried in vacuo at $90^{\circ} \mathrm{C}$, cooled over $\mathrm{P}_{2} \mathrm{O}_{5}$, and reweighed for dry weight determination. A second weighed l-g aliquot was thoroughly suspended in $10 \mathrm{ml}$ anaerobic medium, and serial 10 -fold dilutions were made in anaerobic medium from $10^{-4}$ to $10^{-11} \mathrm{~g} / \mathrm{ml}$. Three $1.0-\mathrm{ml}$ aliquots from each dilution were then inoculated into three tubes containing $9 \mathrm{ml}$ anaerobic medium. Thus, there were three cultures at each level of fecal inoculum from $10^{-4}$ to $10^{-11} \mathrm{~g}$ in five subjects and from $10^{-6}$ to $10^{-11} \mathrm{~g}$ in two others.

Cultures were incubated at $37^{\circ} \mathrm{C}$, and bacterial growth in each was monitored by measuring the increase in optical turbidity at $660 \mathrm{~nm}$. Cultures were harvested within the first $24 \mathrm{~h}$ of stationary growth phase to minimize spurious effects from autolysis of bacteria in older cultures. Cultures inoculated with $10^{-4}$ and $10^{-5} \mathrm{~g}$ feces frequently achieved stationary growth phase at $24-30 \mathrm{~h}$, and such cultures were harvested then; all others were harvested at $48-50 \mathrm{~h}$.

At completion of incubation, the presence or absence of bacterial growth was recorded for each culture. Each culture with growth was streaked onto a blood agar plate, which was incubated aerobically for $72 \mathrm{~h}$ to record the presence or absence of facultative anaerobes. Except where noted, all subsequent steps were performed at $4^{\circ} \mathrm{C}$.

The cultures were centrifuged for $30 \mathrm{~min}$ at $12,000 \mathrm{~g}$ to separate culture supernate from bacterial pellet. A $2-\mathrm{ml}$ aliquot of culture supernate was heated for $5 \mathrm{~min}$ at $100^{\circ} \mathrm{C}$ to inactivate enzymes and was assayed for residual mucin as described below. The remainder of the culture supernate was dialyzed three to four times in 4 liters of $0.1 \mathrm{M} \mathrm{NaCl}$ containing $1 \mathrm{mM}$ $\mathrm{MgCl}_{2}$ and $0.1 \mathrm{mM}$ disodium EDTA. Under these dialysis conditions glycosidase activities were stable for at least $4 \mathrm{wk}$ at $4^{\circ} \mathrm{C}$.

Bacterial disruption. The bacterial pellet from each culture was washed once in $10 \mathrm{ml} 0.1 \mathrm{M} \mathrm{NaCl}$ and resuspended in $8 \mathrm{ml} 0.1 \mathrm{M} \mathrm{NaCl}$ containing $0.5 \% \mathrm{vol} / \mathrm{vol}$ Triton $\mathrm{X}-100$. Bacteria in this suspension were disrupted by ultrasonication for $2 \mathrm{~min}$ at $550 \mathrm{~W}$ in a $2.6 \times 6.5$-cm stainless steel tube immersed in a magnetically stirred ice-water bath using a Branson ultrasonic generator equipped with a macrotip horn (Bran- 
son Sonic Power Co., Danbury, Conn.). Preliminary studies showed that with these conditions the temperature of the sonicated solution remained at or below $10^{\circ}-13^{\circ} \mathrm{C}$, enzyme release was complete, and the addition of $0.5 \%$ Triton $\mathrm{X}-100$ enhanced $\beta-N$-acetylglucosaminidase and sialidase activities in the sonicate fraction 1.3-fold. In 10 studies involving sonication of 180 cultures, the average amount of bacterial protein solubilized under these conditions per study was $82 \%$ (range 70-92\%). After sonication the suspension was centrifuged $30 \mathrm{~min}$ at $12,000 \mathrm{~g}$, yielding a soluble bacterial sonicate fraction and a sediment of bacterial residue. The sonicate fraction was dialyzed in the same manner as the culture supernate.

Enzyme assays. $\beta$-D-Galactosidase, $\beta$ - $N$-acetylglucosaminidase, and $\alpha$-L-fucosidase activities were measured by the rate of release of $p$-nitrophenol from their $p$-nitrophenyl glycosides. $p$-Nitrophenol concentration in the incubation mixture was measured by the optical density at $400 \mathrm{~nm}$ after adding $2.70 \mathrm{ml} 0.5 \mathrm{M} \mathrm{Na}_{2} \mathrm{CO}_{3}$ to $0.30 \mathrm{ml}$ incubation mixture. Sialidase was measured by the rate of release of $N$-acetylneuraminic acid from serum orosomucoid prepared from pooled human serum by the method of Weimer and Winzler (15). $\mathrm{N}$-Acetylneuraminic acid concentration in the incubation mixture was measured by the thiobarbituric acid method of Warren (16). Correction for chromogen formation by 2-deoxypentoses was made by measurements of optical density at 549 and $532 \mathrm{~nm}$ (17). Assays were performed at $37^{\circ} \mathrm{C}$. Each incubation mixture comprised equal volumes of substrate and sample, and contained $0.1 \mathrm{M} \mathrm{NaCl}, 20 \mathrm{mM} \mathrm{N}$ [2-acetamido]-2-aminoethane sulfonic acid (ACES) buffer (18), pH 6.4, $1 \mathrm{mM} \mathrm{MgCl}$, and $0.1 \mathrm{mM}$ disodium EDTA. The assay conditions for each enzyme were such that the rate of product formation was proportional to enzyme concentration. Preliminary studies revealed that the activity of each glycosidase was enhanced when ACES buffer was substituted for phosphate buffer. Even though ACES buffer has metal-chelating properties (18), addition of $0.1 \mathrm{mM}$ disodium EDTA together with $1 \mathrm{mM} \mathrm{MgCl}$ to the incubation mixtures further enhanced $\beta$-D-galactosidase activity without affecting the activities of $\beta$ - $N$-acetylglucosaminidase and sialidase. Parallel incubations of substrate and heat-inactivated samples served as reagent blanks for each assay, and duplicate assays were performed with each sample. A pH of 6.4 was chosen because it is within the optimum $\mathrm{pH}$ range for $\mathrm{ABH}$ blood group-degrading glycosidases (10) and for mucin oligosaccharide degradation in anaerobic fecal cultures. ${ }^{3} 1 \mathrm{mU}$ of activity is defined as the amount of enzyme that releases $1 \mathrm{nmol}$ of product $/ \mathrm{min}$ at $37^{\circ} \mathrm{C}$ and $\mathrm{pH} 6.4$, and is expressed as milliunits per milliliter of each $10 \mathrm{ml}$ culture or as the specific activity milliunits per milligram of bacterial protein. Absence of extracellular $\beta$-D-galactosidase and $\beta$-N-acetylglucosaminidase activities was defined as activity $<0.50 \mathrm{mU} / \mathrm{ml}$, and absence of sialidase as activity $<0.05 \mathrm{mU} / \mathrm{ml}$. Activities less than these fell within the $0+2 \mathrm{SD} \mathrm{mU} / \mathrm{ml}$ range found for assays of 10 replicates of heat-inactivated culture supernates. The operational definition of extracellular enzyme activity is the activity present in each culture supernate, cell bound activity is that present in the bacterial sonicate fraction, and combined activity is the sum of extracellular and cell-bound activity per milliliter of each $10 \mathrm{ml}$ culture or per milligram bacterial protein.

We performed the following study to confirm that assays of $\beta$-D-galactosidase and $\beta$ - $N$-acetylglucosaminidase using their $p$-nitrophenyl glycosidase substrates were valid meas-

${ }^{3}$ Variyam, E. P., and L. C. Hoskins. Manuscript in preparation. ures of their activities in cleaving $\beta$-D-galactose and $\beta$-D-Nacetylglucosamine from glycoprotein oligosaccharides. Dialyzed supernates of 12 different anaerobic fecal cultures were assayed for each activity using the $p$-nitrophenyl glycosides as described above. Then each culture supernate was assayed for $\beta$-galactosidase activity by measuring the rate of release of D-galactose from $10 \mathrm{mg} / \mathrm{ml}$ asialo- $\alpha_{1}$-acid glycoprotein at $\mathrm{pH} 6.4$ and $37^{\circ} \mathrm{C}$. The released galactose was measured by the method of Meisler (19). Each supernate was also assayed for $\beta$ - $N$-acetylglucosaminidase by measuring the rate of release of $N$-acetylhexosamine from $10 \mathrm{mg} / \mathrm{ml}$ asialo-agalacto- $\alpha_{1}$-acid glycoprotein at $\mathrm{pH} 6.4$ and $37^{\circ} \mathrm{C}$. The released $\mathrm{N}$ acetylhexosamine was measured by the method of Reissig et al. (20), using $N$-acetylglucosamine as standard.

Protein concentration. In the bacterial sonicate and residue fractions of each culture, protein concentration was determined by the method of Lowry et al. (21), using crystalline human serum albumin as standard. Bacterial protein concentration was the sum of the protein concentrations in the bacterial sonicate and residue fractions of each $10 \mathrm{ml}$ culture. In six studies, each involving 21 or 22 cultures, optical turbidity at harvest correlated well with bacterial protein concentration (median correlation coefficient $=0.94$, range 0.60 0.98 ). Therefore, bacterial protein concentration was used as a measure of bacterial population density.

Mucin degradation. Mucin degradation during growth of bacteria in each culture was measured as the percent decrease in mucin hexose concentration compared with the concentration in an uninoculated tube of the same batch of culture medium. Ethanol was added to the $2-\mathrm{ml}$ heat-inactivated aliquot from the uninoculated control medium and from each culture supernate to a final concentration of $60 \% \mathrm{vol} / \mathrm{vol}$. The precipitated residual mucin was recovered by centrifugation, reconstituted in $0.1 \mathrm{M} \mathrm{NaCl}$, and assayed for hexose content by the anthrone method of Mokrasch (22), using D-galactose as standard. Cultures in which the decrease in mucin hexose concentration was $\leq 25 \%$ are defined as exhibiting no mucin oligosaccharide degradation. A preliminary study of a culture exhibiting $95 \%$ degradation of mucin hexoses, $56 \%$ degradation of mucin protein, and complete loss of $A$ and $H$ antigen titers revealed no evidence for binding of these mucin constituents to the bacterial pellet.

Estimation of most probable numbers. The most probable numbers (MPN) (23) per gram feces of total bacteria, facultative anaerobes, bacteria producing extracellular glycosidases, and bacteria degrading mucin oligosaccharides were obtained from published tables $(24,25)$. They were determined from the proportion of positive cultures among the replicates from each fecal dilution over the transition between those dilutions in which all replicates were positive and those in which none were positive. The $\log _{10} 95 \%$ confidence limits of the MPN for 10 -fold serial dilutions and three replicates per dilution is \pm 0.670 (23).

Data reduction and statistical tests. To obtain an estimate of fecal sampling variation, five samples, each containing a part of the surface and inner portion, were obtained from different sections of a single stool specimen. Cultures were inoculated with $10^{-2}$ and $10^{-4} \mathrm{~g}$ from each of the samples. The bacterial protein concentration, the percent degradation of mucin hexoses, and the combined cell-bound plus extracellular glycosidase activities were determined at each level of fecal inoculum, and their coefficients of variation $(\mathrm{CV})$ were calculated.

Comparison of intrasubject with intersubject variation of bacterial population density and glycosidase activities at each level of fecal inoculum was made by analysis of variance (26). Bartlett's test (26) was used for assessing homogeneity of variance. 
Because of frequently wide and skewed variations of bacterial population density, percent degradation of mucin hexoses, and glycosidase activities in triplicate cultures inoculated with $<10^{-7} \mathrm{~g}$ feces, nonparametric methods were required for data evaluation. Therefore, for comparison of glycosidase activities at different levels of fecal inoculum the median value within each subject's set of triplicate cultures at each fecal inoculum level was assigned to represent the median value for that subject. The median values of all the subjects at each level of fecal inoculum were next arrayed and the median value of these was assigned as the group median at that level of fecal inoculum. In cultures inoculated with $10^{-11} \mathrm{~g}$ feces, growth occurred in only one of the triplicate cultures from four of the seven subjects. The median values at $10^{-11} \mathrm{~g}$ were derived from the values obtained in the four individual cultures.

A similar method was used to compare glycosidase activities with mucin degradation. Individual cultures from each subject were arrayed within each of three categories, depending upon their exhibiting no (0-25\%), moderate (26-75\%), or extensive (76-100\%) mucin hexose degradation, and the median extracellular and cell-bound enzyme activities were determined within each category. The group median values within each category were then computed from the array of the subjects' individual median values.

Significance of differences between two independent samples was evaluated by the Mann-Whitney $U$ test, and between more than two independent samples by the KruskalWallis one-way analysis of variance by ranks (27). $P$ values $>0.05$ were considered not significant.

\section{RESULTS}

For adequate assessment of findings it was first necessary to $(a)$ define a concentration of HGM in the culture medium that yielded maximum glycosidase activities, $(b)$ determine that $p$-nitrophenyl glycosides are valid substrates for measuring $\beta$-D-galactosidase and $\beta$ - $N$-acetylglucosaminidase activities active on mucin oligosaccharides, and $(c)$ evaluate sampling variations. The results are as follows.

Effect of HGM concentration on bacterial growth and glycosidase production in anaerobic fecal cultures. HGM added to the culture medium increased the bacterial population density and the production of bacterial glycosidases. To establish a concentration of HGM that would yield maximum glycosidase activities in anaerobic fecal cultures, the bacterial population density and glycosidase activities were measured in cultures containing increasing concentrations of HGM and inoculated with $10^{-4} \mathrm{~g}$ feces. The result is shown in Fig. 2. Bacterial population density increased progressively with increasing HGM concentration: at 2 $\mathrm{mg} / \mathrm{ml}$ it had doubled, and at $10 \mathrm{mg} / \mathrm{ml}$ it had tripled. Both $\boldsymbol{\beta}$-D-galactosidase and $\boldsymbol{\beta}$ - $\boldsymbol{N}$-acetylglucosaminidase were enhanced more than fivefold by $1 \mathrm{mg} / \mathrm{ml}$ HGM, and sialidase increased from undetectable levels to $>1 \mathrm{mU} / \mathrm{mg}$. Extracellular activity was enhanced in proportion to the total activity. $p$-Nitrophenyl- $\alpha$-L-fucosidase activity was not enhanced by HGM. Analysis of variance for each of the enzyme activities among cul-

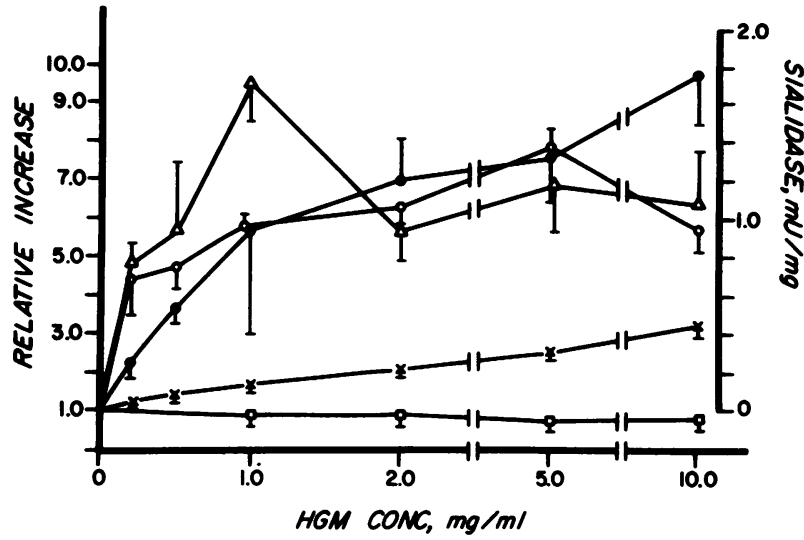

FIGURE 2 Effect of HGM concentration on bacterial population density, measured by bacterial protein concentration, and extracellular plus cell-bound glycosidase specific activities in triplicate cultures inoculated with $10^{-4} \mathrm{~g}$ feces and harvested in early stationary growth phase at $28 \mathrm{~h}$. Except for sialidase, bacterial protein concentration and specific activities are expressed relative to the mean values obtained in the cultures with no HGM. Mean \pm SD (vertical bars) of triplicate cultures. Symbols: $(\times)$, bacterial protein concentration; $(\Theta), \beta$-D-galactosidase; (O), $\beta$ - $N$-acetylglucosaminidase; $(\Delta)$, sialidase; $(\square)$, $\alpha$-L-fucosidase. Conc, concentration.

tures containing 2,5 , and $10 \mathrm{mg} / \mathrm{ml}$ HGM showed that the differences in mean values at these concentrations were not statistically significant. A repetition of this study with a different fecal sample inoculated at $10^{-7}$, $10^{-8}$, and $10^{-9} \mathrm{~g}$ likewise showed no statistically significant differences in the specific activities of the glycosidases among cultures containing 2 and $5 \mathrm{mg} / \mathrm{ml} \mathrm{HGM}$. Accordingly, $2 \mathrm{mg} / \mathrm{ml} \mathrm{HGM}$ was employed throughout this work as a sufficient concentration to stimulate maximal glycosidase activities in anaerobic fecal cultures.

Validation of use of p-nitrophenyl substrates for measuring $\beta$-D-galactosidase and $\beta$-N-acetylglucosaminidase activity acting on mucin oligosaccharides. $\alpha$-Galactosidases and $\alpha$-L-fucosidases active on their corresponding $p$-nitrophenyl glycosides appear to be different enzymes from the $\alpha$-D-galactosidase and $\alpha$-L-fucosidase that cleave the blood group $B$ and the $H$ antigenic determinants $\alpha$-D-galactose and $\alpha$-L-fucose from mucin glycoproteins $(10,28$, unpublished observations). Therefore, it is necessary to verify that assays using synthetic substrates are valid measures of glycosidase activity towards glycoside linkages in glycoprotein oligosaccharides. Fig. 3 shows the results when the $\beta$-D-galactosidase and $\beta$ - $N$-acetylglucosaminidase activities in 12 different anaerobic fecal culture supernates were measured with their $p$-nitrophenyl glycoside substrates and from the rate of cleavage of D-galactose from asialo- $\alpha_{1}$-acid glycoprotein and $N$-acetylhexosamine from asialo-agalacto- $\alpha_{1}$-acid glycoprotein. In each case, rate of cleavage of the $p$-nitrophenyl 


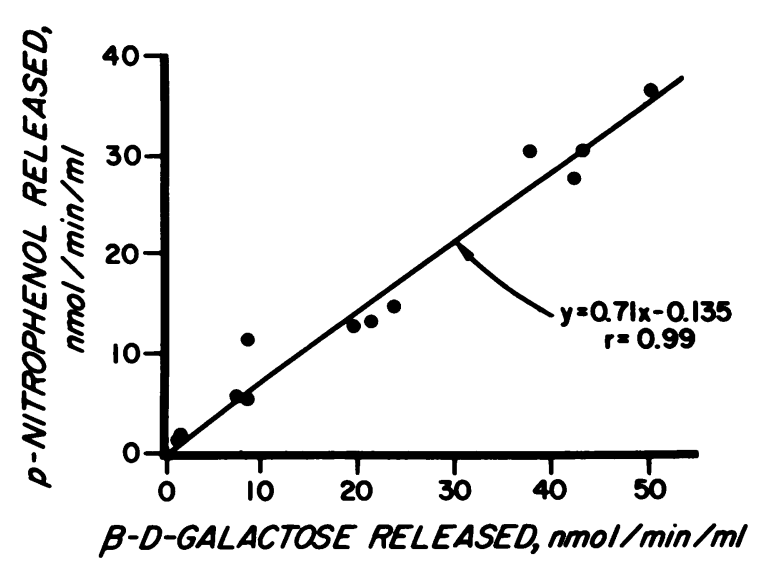

$\beta$-D-GALACTOSE RELEASED, nmol/min/m/

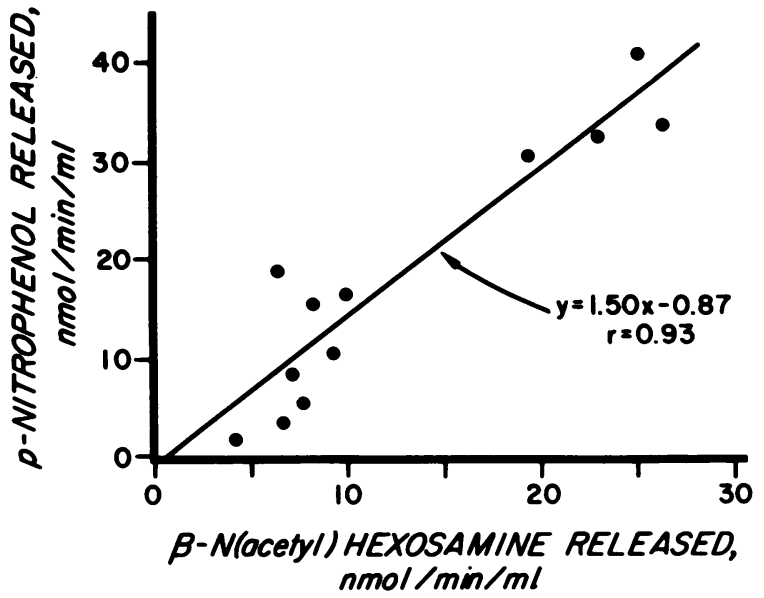

Figure 3 (Left) Correlation of $\beta$-galactosidase activity, measured using $\boldsymbol{p}$-nitrophenyl- $\beta$-D-galactopyranoside, with rate of release of D-galactose from asialo- $\alpha_{1}$-acid glycoprotein. (Right) Correlation of $\beta$ - $N$-acetylglucosaminidase activity, measured using $p$-nitrophenyl- $\beta$-D- $N$-acetylglucosamine, with rate of release of $N$-acetylglucosamine from asialo-agalacto- $\alpha_{1}$-acid glycoprotein. Data points are assays on supernates from 12 different anaerobic fecal cultures. Each line represents the least squares regression equation.

glycoside correlated closely with rate of cleavage of the monosaccharide from its nonreducing terminus on the glycoprotein oligosaccharides. Each least squares regression line extrapolated close to the origin. These results are strong circumstantial evidence that $\beta$-Dgalactosidase and $\beta-N$-acetylglucosaminidase in anaerobic fecal cultures are active against both the synthetic and the natural substrates.

Sampling variations. When the fecal inoculum is heavy, any portion of a stool specimen provides representative values for bacterial population density, percent degradation of mucin oligosaccharides, and glycosidase activities in anaerobic cultures. This is shown in Table I, which lists the mean $\pm \mathrm{CV}$ for each of

TABLE I

Means and CV of Bacterial Protein Percent Degradation of Mucin Hexoses and Glycosidase Activities in Five Cultures, Each Inoculated with $10^{-4} \mathrm{~g}$ Feces from a Different Part of the Same Stool

\begin{tabular}{|c|c|c|}
\hline & Mean & $\mathrm{CV}$ \\
\hline & & $\%$ \\
\hline Bacterial protein concentration & $476 \mu \mathrm{g} / \mathrm{ml}$ & \pm 5.3 \\
\hline Mucin hexose degradation & $96.4 \%$ & \pm 1.1 \\
\hline \multicolumn{3}{|l|}{ Glycosidase activities* } \\
\hline$\beta$-D-Galactosidase & $38.7 \mathrm{mU} / \mathrm{ml}$ & \pm 7.8 \\
\hline$\beta$ - $N$-Acetylglucosaminidase & $25.5 \mathrm{mU} / \mathrm{ml}$ & \pm 10.5 \\
\hline Sialidase & $3.59 \mathrm{mU} / \mathrm{ml}$ & \pm 12.6 \\
\hline$\alpha$-L-Fucosidase & $2.25 \mathrm{mU} / \mathrm{ml}$ & \pm 17.0 \\
\hline Average $\mathrm{CV}$ of glycosidase activities & & \pm 12.0 \\
\hline
\end{tabular}

${ }^{*}$ Extracellular plus cell-bound activity. these in five cultures, each culture inoculated with $10^{-4} \mathrm{~g}$ from a different portion of the same stool. The $\mathrm{CV}$ for bacterial population density, measured as bacterial protein concentration, was $\pm 5 \%$, and for mucin hexose degradation, $\pm 1 \%$; the $\mathrm{CV}$ for the four glycosidase activities ranged from \pm 8 to $\pm 17 \%$ and averaged $\pm 12 \%$. With an even heavier inoculum $\left(10^{-2} \mathrm{~g}\right)$, each $\mathrm{CV}$ was smaller and the average $\mathrm{CV}$ for the four glycosidases was $\pm 8 \%$ (data not shown).

Analysis of variance of bacterial population density and glycosidase activities in cultures from the seven subjects at each level of fecal inoculum from $10^{-4}$ to $10^{-10} \mathrm{~g}$ disclosed that intersubject variation was statistically significantly greater than intrasubject variation in cultures inoculated with $10^{-4}-10^{-7} \mathrm{~g}$ feces. In contrast, substantial intrasubject variations of bacterial population density and glycosidase activities occurred among the triplicate cultures inoculated with $10^{-8}-10^{-10} \mathrm{~g}$ feces from individual samples due to diluting out of both the total bacterial population and the glycosidase-producing populations. These variations introduced significant heterogeneity in the intrasubject variance. Consequently, nonparametric statistical methods were used in all data evaluation.

Effect of fecal inoculum size on bacterial population density and glycosidase activities in anaerobic fecal cultures. Bacterial population density at harvest, measured either by optical turbidity or by bacterial protein concentration, was less in cultures inoculated with $<10^{-7} \mathrm{~g}$ feces (Table II). To correct for differences in the bacterial population density, all glycosidase activities were expressed as the specific activity, milliunits per milligram bacterial protein. 
TABLE II

Group Median Values for Bacterial Protein Concentration and the Specific Activities of Extracellular and Cell-bound Glycosidases in Anaerobic Cultures Inoculated with $10^{-4}-10^{-11} \mathrm{~g}$ Feces from Seven Subjects

\begin{tabular}{|c|c|c|c|c|c|c|c|c|c|}
\hline & \multicolumn{8}{|c|}{ Grams of fecal inoculum } & \multirow{2}{*}{$\begin{array}{l}\text { Significance } \\
\text { of differences }\end{array}$} \\
\hline & $10^{-4}$ & $10^{-5}$ & $10^{-6}$ & $10^{-7}$ & $10^{-8}$ & $10^{-9}$ & $10^{-10}$ & $10^{-11}$ & \\
\hline \multicolumn{10}{|l|}{ Bacterial protein concen- } \\
\hline \multicolumn{10}{|l|}{ Extracellular activity, $\mathrm{mU} / \mathrm{mg}$} \\
\hline$\beta$-D-Galactosidase & 21 & 11 & 12 & 10 & 7.7 & 3.1 & 0.50 & 0 & $P<0.05$ \\
\hline$\beta$ - $N$-Acetylglucosaminidase & 12 & 9 & 14 & 14 & 5.4 & 2.6 & 0.50 & 0 & $P<0.01$ \\
\hline Sialidase & 1.7 & 1.3 & 1.5 & 1.2 & 0 & 0 & 0 & $\mathbf{0}$ & $P<0.02$ \\
\hline$\alpha$-L-Fucosidase & 0.10 & 0.17 & 0.20 & 0.14 & 0.25 & 0.25 & 0.13 & 0 & NS \\
\hline \multicolumn{10}{|l|}{ Cell-bound activity, $\mathrm{mU} / \mathrm{mg}$} \\
\hline$\beta$-D-Galactosidase & 36 & 25 & 30 & 33 & 34 & 26 & 38 & 38 & NS \\
\hline$\beta$ - $N$-Acetylglucosaminidase & 59 & 62 & 67 & 74 & 85 & 61 & 169 & 13 & NS \\
\hline Sialidase & 2.3 & 1.6 & 1.6 & 1.6 & 1.8 & 1.1 & 0.7 & 0 & NS \\
\hline$\alpha$-L-Fucosidase & 6.4 & 6.8 & 6.7 & 4.2 & 4.2 & 1.2 & 8.5 & 0.3 & NS \\
\hline
\end{tabular}

The specific activities of $\beta$-D-galactosidase, $\beta-N$ acetylglucosaminidase, and sialidase showed a consistent pattern in cultures from each of the seven subjects. Extracellular activity of each glycosidase was uniformly present in cultures inoculated with $10^{-4}-10^{-7} \mathrm{~g}$ feces, but below $10^{-7} \mathrm{~g}$ it was diminished or absent from most cultures, so that in those inoculated with $10^{-10}$ and $10^{-11} \mathrm{~g}$ feces, the majority had either no extracellular activity or $<1 \mathrm{mU} / \mathrm{mg}$. The absence of extracellular activity in most cultures inoculated with $\leq 10^{-8} \mathrm{~g}$ feces is evident in Fig. 4, which displays the group-median extracellular activity of each glycosidase, expressed as percent cell-bound plus extracellular activity, in cultures from the seven subjects

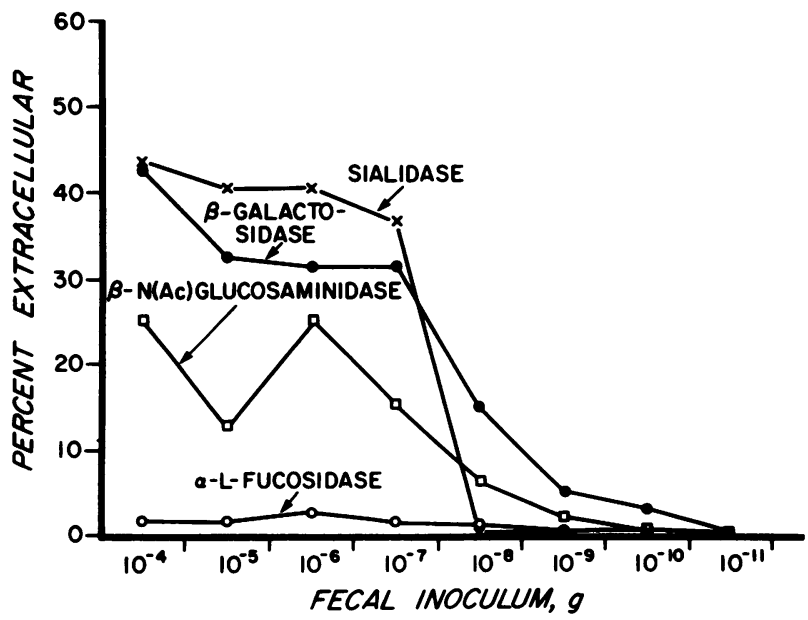

FIGURE 4 Group median values for extracellular activities, expressed as percentage of the cell-bound plus extracellular activity, of four glycosidases in cultures inoculated with $10^{-4}$ $10^{-11} \mathrm{~g}$ feces from seven subjects. throughout the range of fecal inocula. In contrast, cell-bound activity occurred in bacteria growing from all levels of fecal inocula, including $10^{-11} \mathrm{~g}$. This is shown in Table II, where the group median values for extracellular and cell-bound activities at each level of fecal inoculum are summarized. Analysis of variance by ranks of the median extracellular activities of these glycosidases at all levels of fecal inocula disclosed statistically significant differences due to the absence of extracellular activity in many of the cultures inoculated with $10^{-8}-10^{-11} \mathrm{~g}$ feces. In contrast, there were no statistically significant differences in the median cellbound activities throughout the range of fecal inocula.

The substantial extracellular enzyme activities in fecal cultures inoculated with $10^{-4}-10^{-7} \mathrm{~g}$ feces could be due to either extensive autolysis of bacteria during growth or to the presence of subpopulations of bacteria producing extracellular glycosidases that are diluted out when the fecal inocula are $<10^{-7} \mathrm{~g}$. The results with $p$-nitrophenyl- $\alpha$-L-fucosidase strongly suggest that autolysis is an unlikely factor. Like the other glycosidases, it was present in cell-bound form in nearly every culture, including two of the four inoculated with $10^{-11} \mathrm{~g}$ feces (Table II). In contrast, only very small amounts of extracellular activity were found at each level of fecal inoculum, which in $75 \%$ of the cultures did not exceed $0.3 \mathrm{mU} / \mathrm{mg}$ or $5 \%$ of cell-bound plus extracellular activity (Fig. 4). Furthermore, the low levels of its extracellular activity throughout the range of fecal inocula were not statistically significantly different from one another.

Mucin degradation. In all cultures inoculated with $10^{-4}-10^{-6} \mathrm{~g}$ feces, mucin oligosaccharide degradation uniformly exceeded $90 \%$, but at levels of fecal inoculum $<10^{-7} \mathrm{~g}$, the frequency of mucin degradation in cultures decreased. This is shown in Fig. 5, where the 


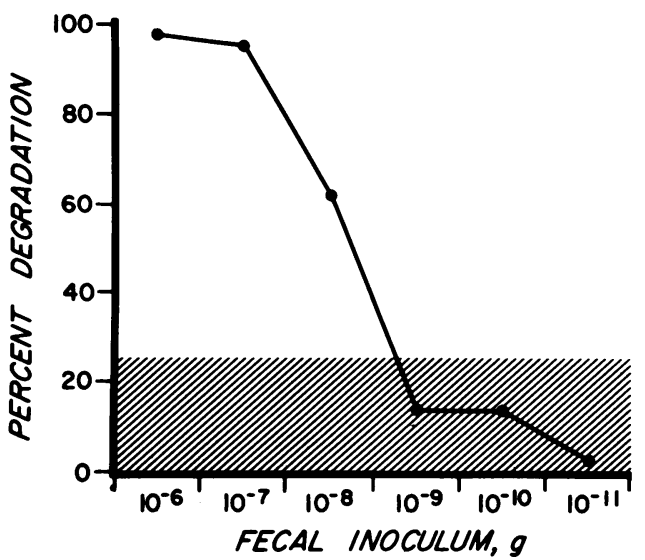

FIGURE 5 Group median values for percent mucin hexose degradation in cultures inoculated with $10^{-6}-10^{-11} \mathrm{~g}$ feces from seven subjects. The shaded area represents the $0-25 \%$ range defined as no degradation.

group median value for percent mucin hexose degradation in cultures from the seven subjects is plotted at each level of fecal inoculum. There is sharp transition from $10^{-7} \mathrm{~g}$, where cultures from five of the seven subjects degraded $>90 \%$ of the mucin hexoses, to $10^{-9} \mathrm{~g}$, where cultures from five of the seven subjects were within the $0-25 \%$ range defined as no mucin degradation. At $10^{-10} \mathrm{~g}$, only one subject's cultures degraded mucin, and no culture with $10^{-11} \mathrm{~g}$ inoculum degraded it.

Since the monosaccharide concentration of the culture medium was growth limiting, glycosidic cleavage of monosaccharides from mucin oligosaccharides should result in greater bacterial population densities in those cultures where the mucin was degraded. This prediction was borne out by the results summarized in Fig. 6. Here the median values for bacterial protein concentration are arrayed against the extent of mucin hexose degradation in cultures inoculated with $10^{-6}-10^{-11} \mathrm{~g}$ feces from each of the seven subjects. Cultures in which the mucin oligosaccharides were extensively degraded had significantly greater bacterial population densities than those with little or no mucin degradation $(P<0.005)$.

Relationship between mucin degradation and extracellular glycosidase activities. In any given culture, degradation of mucin oligosaccharides was associated with the level of extracellular glycosidase activities and not with the level of cell-bound activities. This is shown in Table III, where the group median values for cell-bound and extracellular activities of $\beta$-D-galactosidase, $\beta$ - $N$-acetylglucosaminidase, and sialidase are listed in cultures with no, moderate, or marked degradation of mucin hexoses. There is no relationship between the level of cell-bound activity of each glycosidase and mucin hexose degradation. A strong relationship exists, however, between the level

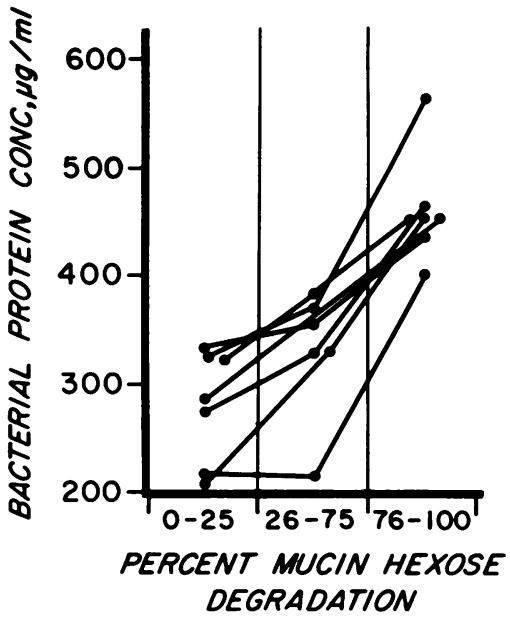

FIGURE 6 Relationship between median values of bacterial population density, measured as bacterial protein concentration, and extent of mucin hexose degradation in cultures inoculated with $10^{-6}-10^{-11} \mathrm{~g}$ feces from each of seven subjects. There is a statistically significant association between bacterial population density and extent of mucin hexose degradation $(P<0.005)$.

of extracellular activity and degradation of mucin hexoses. Statistically significant differences between the glycosidase activities and extent of mucin hexose degradation were present only with extracellular and not with cell-bound activity.

Prolonging the incubation of bacteria possessing cellbound glycosidase activities with HGM did not result in appreciable degradation of mucin oligosaccharides. Thus, in a separate study, five cultures inoculated with $10^{-10} \mathrm{~g}$ feces showed no degradation of mucin hexoses after $99 \mathrm{~h}$ incubation, whereas in one culture inoculated with $3 \times 10^{-10} \mathrm{~g}$ feces there was slight $(34 \%)$ degradation after $88 \mathrm{~h}$.

Estimated fecal population densities of bacteria producing extracellular glycosidases. On the assumption that the extracellular glycosidase activities were produced by subpopulations of fecal bacteria, we estimated their MPN and compared them with the estimated MPN of total bacteria and of those degrading mucin oligosaccharides. The results (Table IV) reveal that the median MPN for bacteria producing each of the extracellular glycosidases was significantly less than that for total bacteria, and ranged from a maximum of $8.4 \%$ of total bacteria to a minimum of $0.004 \%$. Their values did not differ significantly from the MPN of mucin oligosaccharide-degrading bacteria.

Influence of facultative anaerobes. The median (and range) $\log _{10}$ MPN of facultative anaerobes was $8.3(6.0-9.7) / g$ fecal dry wt. There were eight sets of triplicate cultures among five subjects where one or two cultures contained facultative anaerobes and the other did not. Comparison of the extent of mucin degradation 
TABLE III

Association of Mucin Hexose Degradation with Extracellular $\beta$-D-Galactosidase, $\beta$-N-Acetylglucosaminidase, and Sialidase in Anaerobic Cultures Inoculated with $10^{-6}-10^{-11} \mathrm{~g}$ Feces from Seven Subjects

\begin{tabular}{|c|c|c|c|c|c|c|}
\hline \multirow[b]{2}{*}{$\begin{array}{l}\text { Degradation of } \\
\text { mucin hexoses }\end{array}$} & \multicolumn{2}{|c|}{$\beta$-D-Galactosidase } & \multicolumn{2}{|c|}{$\beta-N$-Acetylglucosaminidase } & \multicolumn{2}{|c|}{ Sialidase } \\
\hline & $\begin{array}{l}\text { Extra- } \\
\text { cellular }\end{array}$ & $\begin{array}{l}\text { Cell- } \\
\text { bound }\end{array}$ & $\begin{array}{l}\text { Extra- } \\
\text { cellular }\end{array}$ & $\begin{array}{l}\text { Cell- } \\
\text { bound }\end{array}$ & $\begin{array}{l}\text { Extra- } \\
\text { cellular }\end{array}$ & $\begin{array}{l}\text { Cell- } \\
\text { bound }\end{array}$ \\
\hline$\%$ & \multicolumn{2}{|c|}{$m U / m g$} & \multicolumn{2}{|c|}{$m U / m g$} & \multicolumn{2}{|c|}{$m U / m g$} \\
\hline $0-25$ & $\begin{array}{c}0.6 \\
(0-4)\end{array}$ & $\begin{array}{c}33 \\
(7-105)\end{array}$ & $\begin{array}{c}0.9 \\
(0-19)\end{array}$ & $\begin{array}{c}63 \\
(9-210)\end{array}$ & $\begin{array}{c}0 \\
(0-0)\end{array}$ & $\begin{array}{c}1.50 \\
(0.56-2.0)\end{array}$ \\
\hline $26-75$ & $\begin{array}{c}5.6 \\
(0-10)\end{array}$ & $\begin{array}{c}20 \\
(16-49)\end{array}$ & $\begin{array}{c}3.1 \\
(0-19)\end{array}$ & $\begin{array}{c}84 \\
(47-130)\end{array}$ & $\begin{array}{l}0.07 \\
(0-1.23)\end{array}$ & $\begin{array}{c}1.14 \\
(0.78-2.87)\end{array}$ \\
\hline $76-100$ & $\begin{array}{c}11 \\
(5-82)\end{array}$ & $\begin{array}{c}31 \\
(24-69)\end{array}$ & $\begin{array}{c}13 \\
(7-39)\end{array}$ & $\begin{array}{c}69 \\
(52-120)\end{array}$ & $\begin{array}{c}1.17 \\
(0.56-2.0)\end{array}$ & $\begin{array}{c}1.41 \\
(0.94-1.28)\end{array}$ \\
\hline $\begin{array}{c}\text { Significance of } \\
\text { differences }\end{array}$ & $P<0.01$ & NS & $P<0.02$ & NS & $P<0.01$ & NS \\
\hline
\end{tabular}

Group medians with range of individual subjects' median values in parentheses.

and the four glycosidase specific activities within each set revealed a trend towards higher values in those cultures lacking facultative anaerobes, but the differences were not statistically significant.

\section{DISCUSSION}

Our studies indicate that cell-bound $\beta$-D-galactosidase, $\beta$ - $N$-acetylglucosaminidase, and sialidase are produced by fecal bacteria throughout the range of bacterial population densities found in human feces, but extracellular production of these glycosidases is apparently confined to smaller subpopulations numbering $\sim 10 \%$ g dry fecal wt. We postulate the existence of these subpopulations to account for the absence of extracellular enzyme activity in cultures inoculated at high fecal dilutions. Bacterial autolysis was an unlikely cause of the extracellular activity, since $p$-nitrophenyl$\alpha$-L-fucosidase remained cell bound in cultures throughout the range of fecal inocula. Proof of the ex- istence of discrete subpopulations will require their isolation and the demonstration of extracellular glycosidase production by isolates in pure culture. We are currently undertaking such studies.

Degradation of the oligosaccharide side chains of HGM glycoproteins in individual cultures was strongly associated with extracellular glycosidase production, but not with bacteria whose glycosidase production was limited to cell-bound activity. The latter include the most abundant fecal bacteria, whose population densities numbered $\sim 10^{11 /} / \mathrm{g}$. This suggests that the contribution of the most abundant fecal bacteria to degradation of mucin oligosaccharides within the colon ecosystem is quantitatively minor compared with the contribution of smaller populations producing extracellular glycosidases.

Findings reported here are consistent with our earlier observations $(10,11)$ that the glycosidases cleaving the blood group $\mathrm{A}, \mathrm{B}$, and $\mathrm{H}$ antigenic determinant $\alpha$-glycosides from mucin glycoproteins are

TABLE IV

MPN of Total Bacteria, Bacteria Producing Three Extracellular Glycosidases, and Bacteria Degrading Oligosaccharides of Mucin in Feces from Seven Subjects

\begin{tabular}{|c|c|c|c|c|}
\hline & \multicolumn{2}{|c|}{$\log _{10}$ MPN/g dry wt feces } & \multicolumn{2}{|c|}{ Percent total bacteria } \\
\hline & Median & Range & Median & Range \\
\hline Total bacteria & 11.18 & $10.14-11.38$ & & \\
\hline \multicolumn{5}{|l|}{ Bacteria producing extracellular: } \\
\hline$\beta$-D-Galactosidase & $9.54^{*}$ & $7.15-10.06$ & 4.5 & $0.02-6.5$ \\
\hline$\beta-N$-Acetylglucosaminidase & $9.53^{*}$ & $7.86-10.06$ & 3.9 & $0.5-6.5$ \\
\hline Sialidase & $8.18^{*}$ & $6.49-10.11$ & 0.3 & $0.004-8.4$ \\
\hline Mucin oligosaccharide-degrading bacteria & $9.01^{*}$ & $8.15-11.05$ & 0.9 & $0.2-72.8$ \\
\hline
\end{tabular}

* Differences from MPN of total bacteria, $P=0.001$. 
also produced as extracellular enzymes by subpopulations of fecal bacteria. Their estimated fecal population densities averaged $10^{7}-10^{8} / \mathrm{g}$ wet wt for B-degrading bacteria in group B secretors and for A- and H-degrading bacteria in all 22 subjects (11). Similar consistency for the MPN values of bacteria producing extracellular $\boldsymbol{\beta}$-D-galactosidase, $\boldsymbol{\beta}$ - $\mathrm{N}$-acetylglucosaminidase, and sialidase was present in the seven subjects reported here. Taken together, both studies suggest that bacteria producing extracellular glycosidases represent normal subsets of human fecal flora with comparatively uniform fecal population densities, and that the combined action of their extracellular glycosidases has a major role in the intraluminal degradation of complex oligosaccharides in gut mucin glycoproteins.

The fecal species responsible for extracellular production of the glycosidases we studied are undefined. Nor is it known whether the various glycosidases required for mucin degradation in individual human subjects are all produced by one or a few species, or are each produced by more specialized species working cooperatively. Although aerobes and facultative anaerobes, notably Bacillus (29) and Streptococcus $(30,31)$ species, produce extracellular hydrolases, our findings suggest that their contribution to glycosidase production may be less important than that of obligate anaerobes. Among obligate anaerobes, $\mathrm{Bac}$ teroides species constitute $\sim 20 \%$ of the normal fecal flora. But Salyers et al. (32) found that none of 188 strains from 10 Bacteroides species isolated from human colon contents fermented porcine gastric mucin, and only 3 strains fermented bovine submaxillary mucin. These workers also tested 154 strains from 22 other anaerobic species that were present in concentrations of $\geq 10^{9} / \mathrm{g}$ human feces. Only eight strains fermented porcine gastric mucin, and these were from two species, Ruminococcus torques and Bifidobacterium bifidum (33). The method used by these workers for determining mucin utilization was measurement of the decrease in medium $\mathrm{pH}$ during anaerobic incubation of the cultures. The extent to which this can be equated with production of the various extracellular glycosidases is not known, but their observations are consistent with ours in indicating that degradation of mucin oligosaccharides is a specialized functional activity of one or more subpopulations of human enteric bacteria.

The ecological role of subpopulations producing extracellular glycosidases remains to be defined. It is likely that they provide a nutritional function to the colonic microbial ecosystem as a whole. Thus, most of the strains isolated by Salyers et al. $(32,33)$ used monosaccharides as primary energy sources, including those present in mucin oligosaccharide side chains. Prior cleavage of these monosaccharides by the extracellular enzymes produced by the mucin-degrading subpopu- lations would provide energy sources for more abundant species of human fecal bacteria. This hypothesis is supported by our results showing greater bacterial population densities in cultures where the mucin oligosaccharides were degraded (Fig. 6).

It is also likely that the extracellular glycosidases act on substrates other than mucin glycoproteins in the colon lumen. The oligosaccharides of cell membrane glycolipids (34) and glycoproteins (35), including the disaccharidases of the enterocyte brush border (36), are comprised of glycoside linkages resembling those of mucin oligosaccharides. Damage to the brush border (37) and loss of its disaccharidase activity in bacterial overgrowth syndromes (38) may be due in part to the glycosidases elaborated by these subpopulations. Furthermore, extracellular glycosidases can degrade the surface heteroglycans from the cell walls of the resident enteric bacteria. Thus, loss of the blood group Blike somatic antigen on Escherichia coli 086 during incubation with cell-free fecal extracts and fecal culture supernates appeared to be due to bacterial glycosidases (39). The results of such degradation would be loss of the antigenic specificity normally associated with these structures (40), and perhaps also an attenuation of the pathogenicity of some species of enteric bacteria (41).

It appears legitimate to regard bacteria producing extracellular glycosidases as constituting one or more functionally distinct subpopulations of the human enteric microflora. By degrading mucin oligosaccharides, these subpopulations have a nutritionally supportive role in the enteric microbial ecosystem. Other activities by these subpopulations may be of consequence to human health and will require further investigation.

\section{ACKNOWLEDGMENTS}

We thank our colleagues S. J. Badger, R. K. Fuller, D. Neiderhiser, C. W. Shuster, and E. Variyam of the Departments of Biometry, Medicine, and Microbiology for their helpful suggestions.

This work was supported by a research grant from the Veterans Administration and by the Office of Naval Research Contract N00014-79-C-0034.

\section{REFERENCES}

1. Hoskins, L. C. 1978. Degradation of mucus glycoproteins in the gastrointestinal tract. In The Glycoconjugates. M. Horowitz and W. Pigman, editors. Academic Press, Inc., New York. II: 235-253.

2. Variyam, E. P., and L. C. Hoskins. 1980. Degradation of gut mucin by fecal cultures and fecal extracts. Gastroenterology. 78: A1283.

3. Vercellotti, J. R., A. A. Salyers, W. S. Bullard, and T. D. Wilkens. 1977. Breakdown of mucin and plant polysaccharides in the human colon. Can. J. Biochem. 55: 1190-1196.

4. Hawksworth, G., B. S. Drasar, and M. J. Hill. 1971. In- 
testinal bacteria and the hydrolysis of glycosidic bonds. J. Med. Microbiol. 4: 451-459.

5. Prizont, R., N. Konigsberg, and D. Aminoff. 1976. Glycosidase activity in the rat cecal content. Gastroenterology. 70: A-70/928.

6. Neale, G., J. R. Hopkins, S. Peach, and S. Tabaqchali. 1978. Measurement of glycosidase activity in feces. Gut. 19: A457.

7. Slomiany, B. L., and K. Meyer. 1973. Oligosaccharides produced by acetolysis of blood group active $(\mathrm{A}+\mathrm{H})$ sulfated glycoproteins from hog gastric mucosa. J. Biol. Chem. 248: 2290-2295.

8. Allen, A. 1978. Structure of gastrointestinal mucus glycoproteins and the viscous and gel-forming properties of mucus. Br. Med. Bull. 34: 28-33.

9. Braverman, A., R. A. Miller and L. C. Hoskins. 1980. Fecal population densities of coliforms and mucindegrading bacteria in health and diarrheal illness. Gastroenterology. 78: A1145.

10. Hoskins, L. C., and E. T. Boulding. 1976. Degradation of blood group antigens in human colon ecosystems. I. In vitro production of $\mathrm{ABH}$ blood group-degrading enzymes by fecal bacteria. J. Clin. Invest. 57: 63-73.

11. Hoskins, L. C., and E. T. Boulding. 1976. Degradation of blood group antigens in human colon ecosystems. II. A gene interaction in man that affects the fecal population density of certain enteric bacteria. J. Clin. Invest. 57: 74-82.

12. Jabbal, I., D. I. C. Kells, G. Forstner, and J. Forstner. 1976. Human intestinal goblet cell mucin. Can. J. Biochem. 54: 707-716.

13. Marshall, T., and A. Allen. 1978. The isolation and characterization of the high-molecular-weight glycoprotein from pig colonic mucus. Biochem. J. 173: 569-578.

14. Anaerobe Laboratory Manual. Holdeman, L. V., E. P. Cato, and W. E. C. Moore, editors. Virginia Polytechnic Institute Anaerobe Laboratory, Blacksburg, Va. 4th edition. 1977. $152 \mathrm{pp}$.

15. Weimer, H. E., and R. J. Winzler. 1955. Comparative study of orosomucoid preparations from sera of six species of mammals. Proc. Soc. Exp. Biol. Med. 90: 458-460.

16. Warren, L. 1959. The thiobarbituric acid assay of sialic acids. J. Biol. Chem. 234: 1971-1975.

17. Hoskins, L. C., and N. Zamcheck. 1968. Bacterial degradation of gastrointestinal mucins. I. Comparison of mucus constituents in the stools of germ-free and conventional rats. Gastroenterology. 54: 210-217.

18. Good, N. E., G. D. Wright, W. Winter, T. N. Connolly, S. Izawa, and R. M. M. Singh. 1966. Hydrogen ion buffers for biological research. Biochemistry. 5: 467-477.

19. Meisler, M. 1972. $\beta$-Galactosidase from human liver. Methods Enzymol. 28: 820-824.

20. Reissig, J. E., J. L. Strominger, and L. F. Leloir. 1955. A modified colorimetric method for the estimation of $N$ acetylamine sugars. J. Biol. Chem. 217: 959-966.

21. Lowry, O. H., N. J. Rosebrough, A. L. Farr, and R. J. Randall. 1951. Protein measurement with the Folin phenol reagent. J. Biol. Chem. 193: 265-275.

22. Mokrasch, L. C. 1954. Analysis of sugar phosphates and sugar mixtures with the anthrone reagent. J. Biol. Chem. 208: 55-59.

23. Cochran, W. G. 1950. Estimation of bacterial densities by means of the "most probable number." Biometrics. 6: $105-116$.

24. deMan, J. C. 1975. The probability of most probable numbers. Eur. J. Appl. Microbiol. 1: 67-78.

25. Hoskins, J. K. 1934. Most probable numbers for evaluation of Coliaerogenes tests by fermentation tube method. U. S. Public Health Rep. (Wash. D. C.) 49: 393-405.

26. Snedecor, G. W., and W. G. Cochran. 1967. Statistical Methods. Iowa State University Press, Ames Iowa. 6th edition. 593 pp.

27. Siegel, S. 1956. Nonparametric Statistics for the Behavioral Sciences. McGraw-Hill, Inc., New York. 312 pp.

28. Aminoff, D., and K. Furukawa. 1970. Enzymes that destroy blood group specificity. I. Purification and properties of a $\alpha$-L-fucosidase from Clostridium perfringens. J. Biol. Chem. 245: 1659-1669.

29. Priest, F. G. 1977. Extracellular enzyme synthesis in the genus Bacillus. Bacteriol. Rev. 41: 711-753.

30. Pinter, J. K., J. A. Hayashi, and A. N. Bahn. 1969. Carbohydrate hydrolases of oral streptococci. Arch. Oral Biol. 14: 735-744.

31. Glasgow, L. R., J. C. Paulson, and R. L. Hill. 1977. Systematic purification of five glycosidases from Streptococcus (Diplococcus) pneumoniae. J. Biol. Chem. 252: 8615-8623.

32. Salyers, A. A., J. R. Vercellotti, S. E. H. West, and T. D. Wilkins. 1977. Fermentation of mucin and plant polysaccharides by strains of Bacteroides in the human colon. Appl. Environ. Microbiol. 33: 319-322.

33. Salyers, A. A., S. E. H. West, J. R. Vercellotti, and T. D. Wilkins. 1977. Fermentation of mucins and plant polysaccharides by anaerobic bacteria from the human colon. Appl. Environ. Microbiol. 34: 529-533.

34. Sweeley, C. C., and B. Siddiqui. 1977. Chemistry of mammalian glycolipids. In The Glycoconjugates. M. I. Horowitz and W. Pigman, editors. Academic Press, Inc., New York. I: 459-540.

35. Takaski, S., K. Yamashita, and A. Kobata. 1978. The sugar chain structures of $\mathrm{ABO}$ blood group active glycoproteins from human erythrocyte membrane. J. Biol. Chem. 253: 6086-6091.

36. Kelly, J. J., and D. H. Alpers. 1973. Blood group antigenicity of purified human intestinal disaccharidases. $J$. Biol. Chem. 248: 8216-8221.

37. Toskes, P. P., R. A. Gianella, H. R. Jervis, W. R. Rout, and A. Takeuchi. 1975. Small intestinal mucosal injury in the blind loop syndrome. Gastroenterology. 68: 1193-1203.

38. Giannella, R. A., W. R. Rout, and P. P. Toskes. 1974 Jejunal brush border injury and impaired sugar and amino acid uptake in the blind loop syndrome. Gastroenterology. 67: 965-974.

39. Cromwell, C. L., and L. C. Hoskins. 1977. Antigen degradation in human colon ecosystems. Host's ABO blood type influences enteric bacterial degradation of a cell surface antigen on Escherichia Coli 086. Gastroenterology. 73: $37-41$.

40. Orskov, I., F. Orskov, B. Jann, and K. Jann. 1977. Serology, chemistry and genetics of $O$ and $K$ antigens of Escherichia coli. Bacteriol. Rev. 41: 667-710.

41. Smith, H. Microbial surfaces in relation to pathogenicity. 1977. Bacteriol. Rev. 41: 475-500. 